\title{
On Implements and Chips From The Floor Of A Palæolithic Workshop
}

\section{F. C. J. Spurrell}

To cite this article: F. C. J. Spurrell (1880) On Implements and Chips From The Floor Of A Palæolithic Workshop, Archaeological Journal, 37:1, 294-299, DOI: 10.1080/00665983.1880.10851939

To link to this article: http://dx.doi.org/10.1080/00665983.1880.10851939

冓 Published online: 14 Jul 2014.

Submit your article to this journal $\lceil\pi$

Џ Article views: 1

a

View related articles $₫$ 
ON IMPLEMENTS AND CHIPS FROM THE FLOOR OF $A$ PALAEOLITHIC WORKSHOP. ${ }^{1}$

By F. C. J. SPURRELL.

The chips which I exhibit and their restoration to position in the block, represent the remains found on a sandy beach of the ancient river Thames, under its chalk cliff, when the river was nearly two miles wider on that (south) side than it is now.

They lay on a slope, from thirty-six to nearly forty-one feet below the present surface of the ground and about thirty-five feet above the present high water mark of spring tides.

This ancient river in working its way had cut cliffs, in some places, a hundred feet or more in height, with occasional "gates," as they are called in Kent, or ways down to the water; and it was gently filling up again the gully it had made with debris brought from its basin. Sometimes the river, whether from tidal or other causes, left sandy margins below the cliffs constituting its banks. Under one such cliff, running north and south, and at one of these "gates," is the place $I$ am describing; the accompanying sketch is from the section actually in view, in the chalk pit, very nearly half a mile N.N.t. of Crayford Church, Kent.

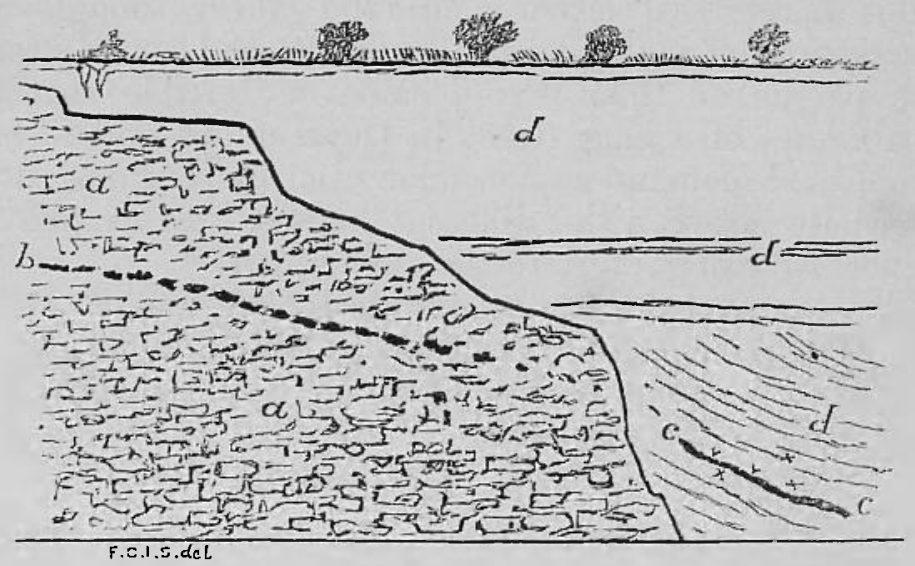

$a u$, chalk cliff; $b$, band of flints ; $c$, layer of chips ; $d d$, sand clays.

1 Read at the Monthly Meeting of the Institute, July 1st, 1880. 


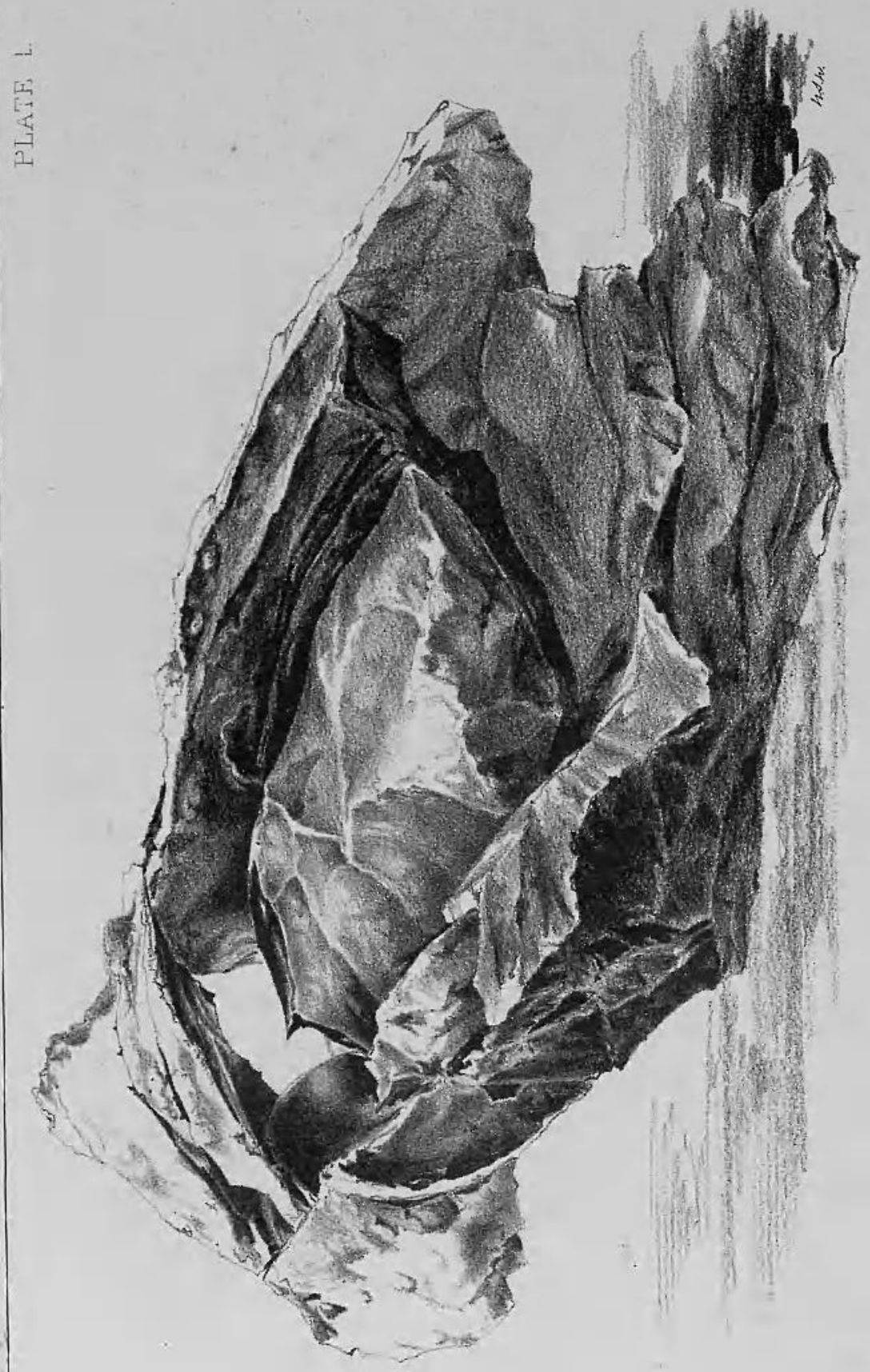

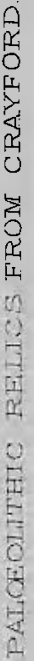


Near this place were many blocks of flint stone which had fallen on the shore from out of the cliffs above, and the "Palæolithic" man (excuse the awkward phrase) sitting on the beach or fore shore, on a suitable, spot of the cleanest hard sand, chipped the flints into the shapes required by his wants. The blocks of weathered and bruised flint were obstinate and flawed, and great difficulty was experienced in getting good pieces to work upon, which contentment with inferior stone proves his inability to mine it from the rock, besides the fact that there are no such excavations in the ancient cliff. hereabouts, (unlike the "Neolithic" man, a description of whose mines, within fifty yards of this spot, is printed at page 332), and it is lucky that it it was so, for we have before us a hache, which in making he had split and thrown away. Its length is 4.4 by 3.1 inches. I have built up around it the pieces he struck off, so as to shew his method, a wild one, betokening great necessity and little art. The upper half of the "restoration" has been lifted off, to shew the interior. Its dimensions are 10.5 by 5.5 inches. (See plate I).

Another block is "restored," shewing that the object was to obtain flakes for smaller implements, such as arrow-heads, knives, \&c. Its greatest width is $4 \cdot 2$ inches. Very many flakes appear to have been used at their broad ends. (See plate II, fig. 1).

There are two stones, which have been employed as strikers or hammers; one, a green coated flint (here engra-

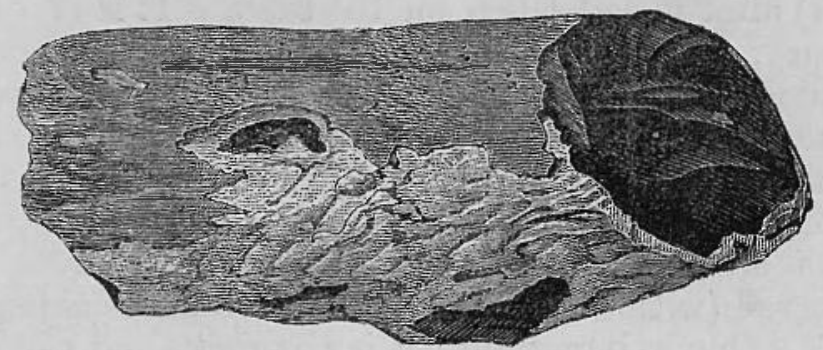

ved), which, having been chosen to suit the grasp of the hand, had been trimmed at either end to further that intent, and it is peculiarly suited to the work for which it was chosen; the thick layer of tough crust on one side of it enabled the blow to be delivered with precision, and its 
own wear was reduced thereby, while it was not until continued use had worn away this coat down to the black splintery stone that it was thrown aside. Its dimensions are 3.8 in length and 6.7 circumference. The other is smaller, and appears to have been merely used tentatively.

The work was done on the spot where I found the chips and tools, for they lay each near the other as they originally fell; some, having fallen over others, broke, and I found two long flakes broken in halves, with the ends scarcely separated, which are studded on the opposed surfaces with crystalline concretions, contracted after breaking, and of course while still in the soil; thus shewing that there was no water at that spot when they fell. Then all the edges are perfectly sharp; this would not have been the case had they been rolled or rubbed over each other ; from the cleanness of the sand in which they lay no dirt had been contracted, but that which could be easily removed, and which from its being found only on the upper side, I take to be blown dust or rain splash. A few crystalline concretions of carbonate of lime stud some flakes here and there (Plate $\pi$, fig. 2) while rough spots of iron oxide are occasionally found on them, cementing a few to each other or to particles of bone.

The finer and most minute splinters lay in a thin layer unmixed with sand, and I have one flake from which a minor splinter has separated (the result of continued action from the same blow which separated it from the block) after it had fallen on the sand. It is of extreme delicacy, and is still in apposition, being preserved by steeping it in gum water. This proves that the position of the workman was a sitting one.

Among the chips and above them were numerous pieces of bone, the remains of extinct animals, with which these works are associated, some specimens I have luckily preserved (with great care) which have flakes adherent to them. One is important; it is the right, and part of the left ramus of the lower jaw of the Rhinoceros tichorhinus, containing all the milk molars and premolars; the alveoli of the outer incisors (shed) were intact, and the inner incisors just visible. It is broken in half. The two pieces lay about eighteen inches off each other on the 


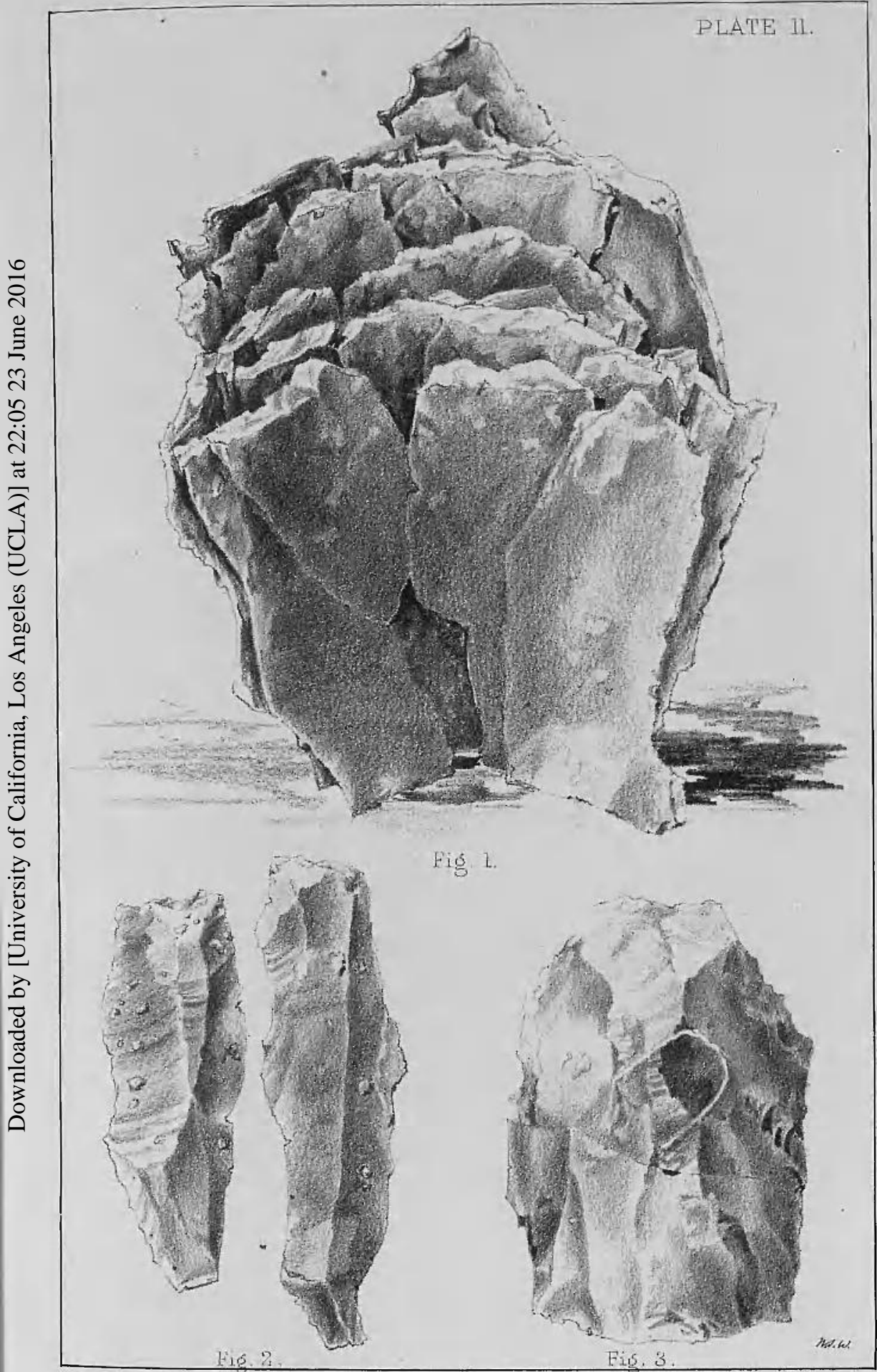

PALCEOIITHIC RELICS FROM CRAYFORD. 
flakes, of which three adhere still; a small and delicate half formed tooth of the coming series, from the body of this jaw, lay close by.

These bones were broken, they had been either slightly worn or gnawed, but some of the bones of the gigantic pachyderms had been splintered. I cannot find the marks of teeth of hyæna, and I incline to the belief that they are the remains of beasts used as food. The big blocks of stone lying on the beach at hand would serve to crush anything. A large bone which I found shews cracks and considerable weathering, the result of exposure in a fresh state before being covered by the sand.

This spot appears to have been a chipping ground for ages ; indications of several layers are visible, extending at least a dozen feet above that first described, while others may be found below.

The bones of the animals actually in contact with the flints belonged to several sorts, but the young and old of rhinoceros tichorhinus and the mammoth are easily identified. Without going too deeply into the subject, I shall notice the animals with which the man who worked here was contemporary, in order to realize-

1. What game he trapped or preyed on.

2. The probable extremes of climate he struggled against.

3. The far distant period of time to which, by their clear connexion with earlier geologic eras, he is relegated.

There are but eighteen mammals summed up by Professor Boyd Dawkins in his recent book (Early Man in Britain), as found in these brick-earths, in which human handiwork is found commingled, to them I shall add the dog, fox, the roe? and wild boar. Thus we have, surviving from the-

Pliocene-The rhinoceros megarhinus.

Early Pleistocene-The brown bear, wolf, urus, horse, Irish elk, mammoth, straight tusked elephant, lion, spotted hyæna, grisly bear, bison, wild boar, musk sheep, marmot. fox, red deer, roe? water rat.

Mid Pliocene (in which man first appears)-Rhinoceros tichorhinus, rhinoceros leptorhinus, canis.

All the above are now extinct in this country, except VoL. XXXVII. 
the dog, fox, red deer, water rat, and the roe, or a similar small deer.

Some of the animals required a warm climate, and some an arctic, as the musk sheep and the marmot, several of which last I found in a mass, drowned whilst hybernating.

How came the "man" to leave these apparently valuable remains, is a question often asked. I cannot tell, perhaps an offensive beast or an enemy frightened him away, perhaps a great storm forced him to seek shelter, the results of which, in the rise of the river, and the layer of mud brought down by the flood, covering up the spot, prevented his return; but many another cause can be easily surmized.

Though from many blocks the majority of flakes may recovered and recognized, yet it is clear, on the other hand, that from other blocks but few pieces can be retrieved, and these were of better quality and more compliant to the striker.

A word as to the relation of this "man's" works to those before and after him in the immediate neighbourhood.

The water once had its level above the top of Shooter's Fill, this appears to have been the sea, but as it got lower it became estuarine, leaving terraces, now only represented by patches of gravel at different heights. From that at 400 feet on Shooter's Hill down to that at 100 feet on Dartford Heath and Crayford no implement lias been procured "in situ," but I found a large implement (of the broad Abbeville type) at an elevation of 175 feet on Northumberland Heath, Erith, which had been rolled and stained a bright yellow ; this, though found on the surface, I believe to have been a relic of a gravel patch since removed.' But in the Dartford heath layer I found a "hache" "in situ," which was figured by Mr. J. Evans in his Ancient Stone Implements of Great Britain, and which he has kindly allowed me to reproduce here, while another was found by $\mathrm{Mr}$. C. C. Fooks in the same gravel last year.

\footnotetext{
1 It had been used as a tool for freeing a horse-hoo from weeds, and was much worn thereby, before I succeeded in rescuing it.
} 


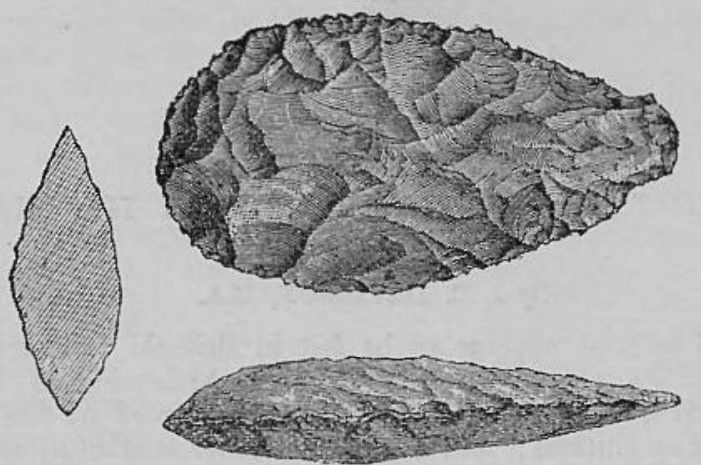

The river then descended slowly to about its present level, a hundred and fifty feet below that last mentioned, when it began to deposit very gently the "lower brickearths of the Thames valley," as they are called, being the debris from the lands and cliffs adjacent, among others the higher gravels of the old river, and it is from these, perhaps the nearest, that (looking at their situation, mineral condition, and wear) I believe the earliest flint flakes recorded as being found at Crayford were clerived; viz., those by the Rev. O. Fisher, Mr. Cheadle ("one considerably worn "), and Dr. Gladstone, F.R.S., while I have found one or two which I feel sure have a like history.

The water meanwhile got higher and higher, reaching the 100 feet level again. During this last rise and deposit of mud these chips were covered up. Then the river slowly went down, and in its latest deposit, the marsh clay and forest bed, may be found the latest implements of the stone-using times.

These rises and falls are of course only relative, as they are due in this case to motions of the earth, and but little to changes in the sea level, and were gradual and of long: continuance.

PLATE I.

Large "restoration" with hiche inside.

\section{PLATE II.}

Fig. 1. Small "restoration."

Fig. 2. Loug flake, 5.0 by 1.5 inches.

Short flake, 4.1 by 1.6 inches.

Fig, 3. The hache from large "restorition." 